\title{
Detection of the $h b l$ complex genes in Bacillus cereus isolated from cow raw milk in northwest of Iran
}

\author{
R. Alipour Banaei ${ }^{1}$ and S. Mahdavi ${ }^{2 *}$ \\ ${ }^{1}$ Department of Genetics, Tabriz Branch, Islamic Azad University, Tabriz, ${ }^{2}$ Department of Microbiology, Maragheh Branch, \\ Islamic Azad University, Maragheh, Iran, "Email: S.mahdavi@iau-maragheh.ac.ir
}

(Received September 20, 2019; Accepted February 21, 2020; Available online August 15, 2020)

\begin{abstract}
Bacillus $(B)$ cereus is regarded as a major foodborne pathogen which is widely distributed in the nature. In addition, it plays an important role in the contamination of ready-to-eat and dairy products. B. cereus causes the two different types of food poisoning in human: the diarrheal and the emetic type. The aim of this study is detection of $h b l$ complex genes in $B$. cereus isolated from cow raw milk in Northwest of Iran. In the present study, the number of the samples collected from cow raw milk were 120. All the isolates already had been identified phenotypically, and they were assessed for molecular confirmation by using the PCR method. B. cereus isolates were determined by detecting the $h b l$ genes complex in the isolates. The result of this study showed that $B$. cereus were found in the raw milk samples $117(97.5 \%)$ from the 120 samples. The frequency of the $h b l \mathrm{~A}, h b l \mathrm{C}$, and $h b l \mathrm{D}$ genes found in $B$. cereus isolates were 105 (89.7\%), $102(87.1 \%)$, and $102(87.1 \%)$, respectively. 99 isolates $(84.6 \%)$ harboured 3 tested genes simultaneously. 12 B. cereus isolates $(10.3 \%)$ lacked these genes. The results of current study showed that $B$. cereus isolated from raw milk have high potential in causing food poisoning and therefore the use of the procedures to reduce the bacterial contamination during the processing of dairy product is required.
\end{abstract}

Keywords: Bacillus cereus, raw milk, hbl genes complex

DOI: 10.33899/ijvs.2020.126120.1238, @2020, College of Veterinary Medicine, University of Mosul.

This is an open access article under the CC BY 4.0 license (http://creativecommons.org/licenses/by/4.0/).

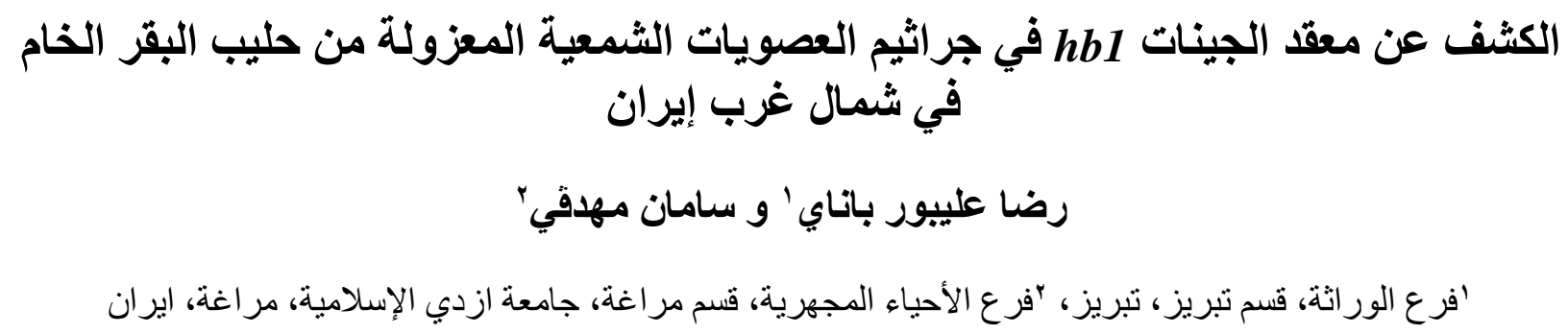

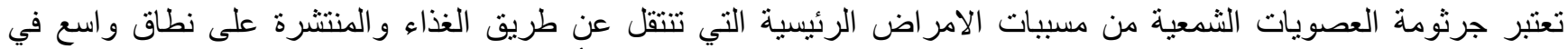

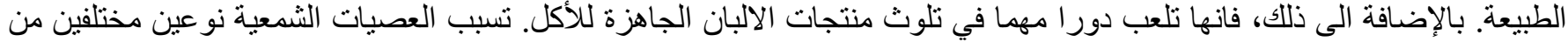

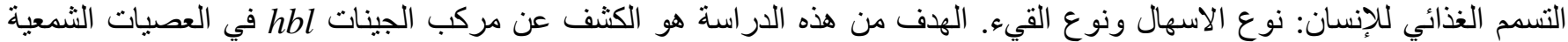

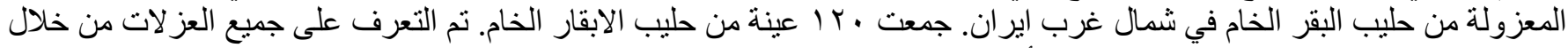

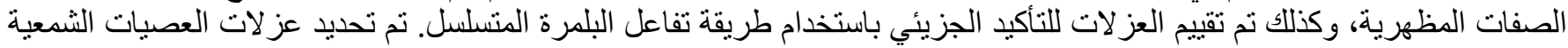

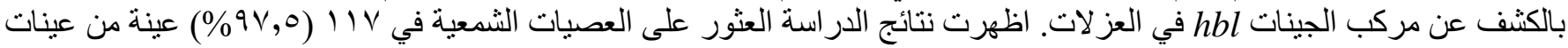

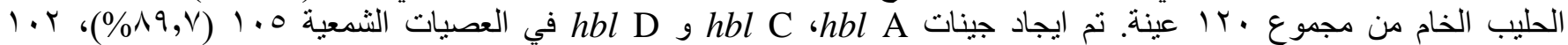

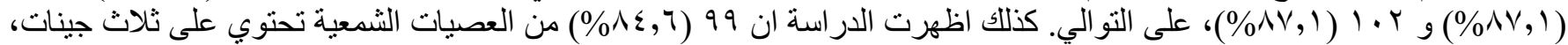

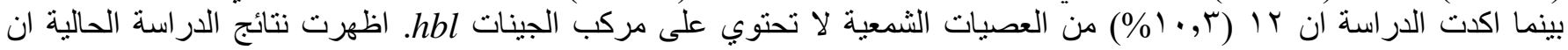




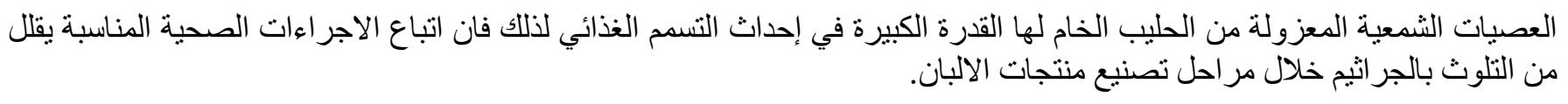

\section{Introduction}

Foodborne disease is regarded as a one of the most important disease which causes a serious problem in developed and developing countries (1). Raw milk is considered a good medium for growth and proliferation of the algae, protozoans, fungi, bacteria, and viruses because it has the most important nutrition factors. There are many types of pathogenic bacteria have been isolated from raw milk, some of these pathogenic bacteria are able to form spores and can tolerate the pasteurization conditions. $B$. cereus is one of the most important pathogens that tolerates the pasteurization process (2). This bacterium is usually a source of raw milk contamination and a major microbiological problem in the dairy industry. The heat resistant of the $B$. cereus spores is a source of contamination for milk products (3). B. cereus has many pathogenicity factors which causes diarrhea associated with production of enterotoxins such as the hemolysin BL $(h b l)$, nonheliolateral enterotoxin (NHE), cytotoxin $\mathrm{K}$, and FM enterotoxin (4). B. cereus produces the toxin in the small intestine that causes food poisoning and diarrhea (5). The hemolysin BL toxin is consisting of a three-component protein complex (6), which is formed from a sticky component (B) and two lithic components ( $1 \mathrm{~L}$ and $2 \mathrm{~L}$ ), that coded the $h b l A, h b l D$, and $h b l C$ genes, respectively. The presence of the three genes are necessary for maximum activity and poisoning (7). The B. cereus infectious dose which causes the food poisoning is $10^{4}-10^{11}$ cells per 1 gram of food. The exact amount of toxin depends on the several factors, such as presence of vegetative bacterial cells, sporulated form in food, amount of produced enterotoxins, and the sensitivity of target cell population (8$10)$. The aim of this study was to detect the $h b l$ complex genes in $B$. cereus isolated from raw cow's milk in Northwest of Iran.

\section{Materials and methods}

\section{Samples collection}

In this study, 300 cow raw milk samples collected from different regions in northwest of Iran (the period of collect the samples was from April to October in 2018). All the samples were tested by using the culture and biochemical tests to detect the characteristics of $B$. cereus isolates and finally, $120 \mathrm{~B}$. cereus isolates were identified and they were sent to molecular identification by using PCR method.

\section{Molecular detection of $\boldsymbol{B}$. cereus and the $h b l$ complex genes}

DNA extraction of the B. cereus isolates was performed by using the DNA extraction kit (Pak Gene Yakhteh company, Iran). The quality of extracted DNA samples was evaluated by using the Nano Drop instrument and suitable samples to select for the next steps. The B. cereus specific primers used in the present study (Nano Zist Fanavaran company, Iran) (Table 1).

The PCR reaction was performed in a total volume of $20 \mu$ containing $10 \times \mathrm{PCR}$ buffer $2 \mu \mathrm{l}, \mathrm{MgCl}_{2} 2 \mathrm{mM}$, dNTP $0.2 \mathrm{mM}$, specific primers $(0.25 \mu \mathrm{M})$, Taq DNA polymerase $1.5 \mathrm{U}$, and extracted DNA $4 \mu \mathrm{l}$ using the thermal cycler (Astec, Japan). The PCR conditions for each gene are presented in the Table 2. The obtained PCR products were electrophoresed on $1.5 \%$ agarose gel (11).

\section{Results}

The result of this study decleared that B. cereus found in the 117 samples from the 120 investigated samples which were previously detected by using biochemical tests, and they were confirmed as B. cereus by using PCR reaction (Figure 1).

Table 1: Sequence of primers used for detection of B. cereus and the $h b l$ complex genes

\begin{tabular}{|c|c|c|c|}
\hline Gene & Sequence $\left(5^{\prime}-3^{\prime}\right)$ & Amplicon size & Reference \\
\hline Bal & $\begin{array}{l}\text { F: 5'-TGCAACTGTATTAGCACAAGCT-3' } \\
\text { R: 5'-TACCACGAAGTTTGTTCACTACT-3' }\end{array}$ & 533 bp & 9 \\
\hline hbla & $\begin{array}{l}\text { F: 5'-GTGCAGATGTTGATGCCGAT-3' } \\
\text { R: 5'-ATGCCACTGCGTGGACATAT-3' }\end{array}$ & $320 \mathrm{bp}$ & 10 \\
\hline$h b l c$ & $\begin{array}{l}\text { F: 5'-AATGGTCATCGGAACTCTAT-3' } \\
\text { R: 5'-CTCGCTGTTCTGCTGTTAAT-3' }\end{array}$ & $750 \mathrm{bp}$ & 10 \\
\hline$h b l D$ & $\begin{array}{l}\text { F: 5'-AATCAAGAGCTGTCACGAAT-3' } \\
\text { R: 5'-CACCAATTGACCATGCTAAT-3' }\end{array}$ & $430 \mathrm{bp}$ & 10 \\
\hline
\end{tabular}


Table 2: The thermocycler programs for detection of B. cereus and $h b l$ complex genes

\begin{tabular}{lcccccc}
\hline \multirow{2}{*}{ Primer } & \multicolumn{5}{c}{ Temperature $\left({ }^{\circ} \mathrm{C}\right) /$ Time $(\mathrm{sec} / \mathrm{min})$} & \multirow{2}{*}{ Cycle } \\
\cline { 2 - 5 } & Initial denaturation & Denaturation & Annealing & Extension & Final extension & \\
\hline Bal & $94^{\circ} \mathrm{C}(03: 00)$ & $94^{\circ} \mathrm{C}(00: 30)$ & $54^{\circ} \mathrm{C}(00: 45)$ & $72^{\circ} \mathrm{C}(01: 00)$ & $72^{\circ} \mathrm{C}(05: 00)$ & 35 \\
$h b l A$ & $94^{\circ} \mathrm{C}(04: 00)$ & $94^{\circ} \mathrm{C}(00: 30)$ & $58^{\circ} \mathrm{C}(00: 45)$ & $72^{\circ} \mathrm{C}(01: 00)$ & $72^{\circ} \mathrm{C}(05: 00)$ & 35 \\
$h b l C$ & $94^{\circ} \mathrm{C}(03: 00)$ & $94^{\circ} \mathrm{C}(00: 30)$ & $53^{\circ} \mathrm{C}(00: 45)$ & $72^{\circ} \mathrm{C}(01: 00)$ & $72^{\circ} \mathrm{C}(05: 00)$ & 35 \\
$h b l D$ & $94^{\circ} \mathrm{C}(04: 00)$ & $94^{\circ} \mathrm{C}(00: 30)$ & $54^{\circ} \mathrm{C}(00: 45)$ & $72^{\circ} \mathrm{C}(01: 00)$ & $72^{\circ} \mathrm{C}(05: 00)$ & 35 \\
\hline
\end{tabular}

The Figure 2 showed that the rate of the hbla gene found in the B. cereus isolates was $89.7 \%(105 / 117)$. In addition, the Figure 3 appeared that the rate of the $h b l C$ gene found in the B. cereus isolates was $87.1 \%(102 / 117)$. Moreover, the Figure 4 declared that the rate of the $h b l D$ gene found in the B. cereus isolates was $87.1 \%$ (102/117). Also, all the three genes were detected in the B. cereus isolates $99(84.6 \%)$. In the other hands, 12 isolates of $B$. cereus $(10.25 \%)$ were without studied genes (Table 3 ).

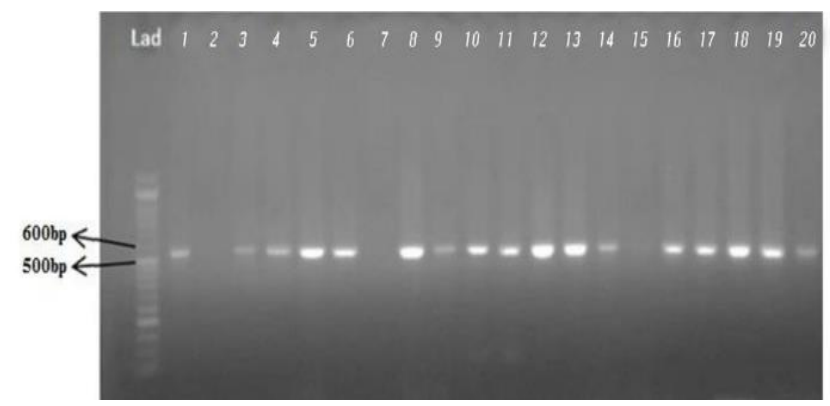

Figure 1. Electrophoresis of the bal gene PCR product on $1.5 \%$ agarose. Lad: ladder $50 \mathrm{bp}$; No. 1: positive control $(B$. cereus ATCC 11778); No. 2: negative control (doubledistilled water); No. 3-6 and 8-14 and 16-20: positive $B$. cereus samples; No. 7 and 15: negative $B$. cereus sample.

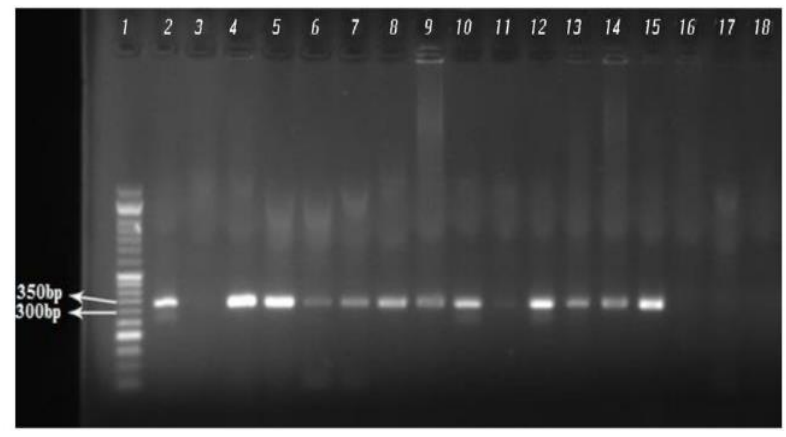

Figure 2. Electrophoresis of the balA gene PCR product on $1.5 \%$ agarose. No. 1: ladder 50 bp; No. 2: positive control (B. cereus ATCC 11778); No. 3: negative control (doubledistilled water); No. 4-15: positive B. cereus samples; No. 16-18: negative $B$. cereus sample.

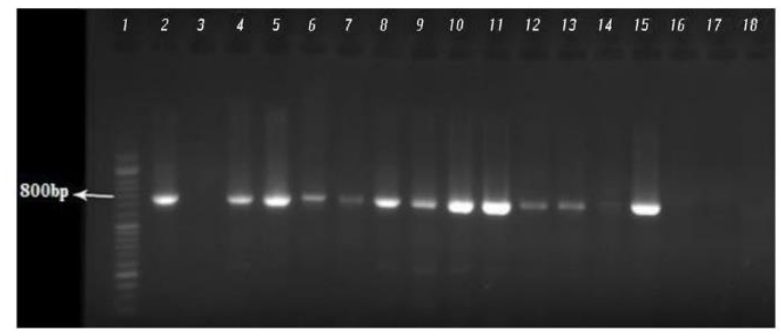

Figure 3. Electrophoresis of the balC gene PCR product on $1.5 \%$ agarose. No. 1: ladder 50 bp; No. 2: positive control (B. cereus ATCC 11778); No. 3: negative control (doubledistilled water); No. 4-15: positive B. cereus samples; No. 16-18: negative B. cereus sample.

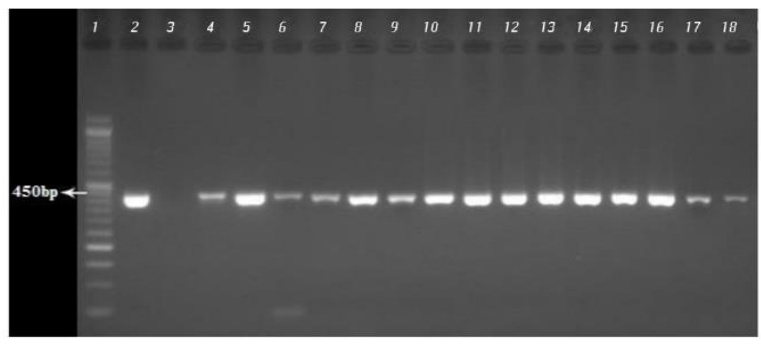

Figure 4. Electrophoresis of the balD gene PCR product on $1.5 \%$ agarose. No. 1: ladder $50 \mathrm{bp}$; No. 2: positive control (B. cereus ATCC 11778); No. 3: negative control (doubledistilled water); No. 4-18: positive B. cereus samples.

Table 3. Frequency of $h b l$ complex genes in studied isolates

\begin{tabular}{lcc}
\hline Genes & Isolates number & Frequency (\%) \\
\hline$h b l A$ & 105 & $89.7 \%$ \\
$h b l C$ & 102 & $87.1 \%$ \\
$h b l D$ & 102 & $87.1 \%$ \\
$h b l A+h b l C$ & 102 & $87.1 \%$ \\
$h b l A+h b l D$ & 102 & $87.1 \%$ \\
$h b l C+h b l D$ & 99 & $84.6 \%$ \\
$h b l A+h b l C+h b l D$ & 99 & $84.6 \%$ \\
\hline
\end{tabular}

\section{Discussion}

In present study, 120 cow raw milk samples collected from different regions in Northwest in Iran. All the $B$. 
cereus isolates were previously detected by using the phenotypic culture and the biochemical tests. After PCR reaction by using the specific primers, 117 B. cereus isolates were detected as a $B$. cereus, genetically. This indicates a higher accuracy of PCR method than the culture biochemical tests. The rapid methods for identify presence of enterotoxigenic B. cereus in foods is very important to ensure the foods hygiene. The culture and Biochemical tests are less accurate compared with the PCR reaction, which is more accurate and more reliable. In the present study, the frequency of $h b l A, h b l C$ and $h b l D$ genes were showed 105 $(89.7 \%), 102(87.1 \%)$ and $102(87.1 \%)$, respectively. In the previously study by Kim et al. (12) in South Korea reported that the prevalence of $h b l A$ and $h b l C$ genes in standard strains of B. cereus were $6.25 \%$, and the frequency of $h b l D$ gene was $25 \%$. In another study showed that only $12.5 \%$ of the isolates had all the three genes, simultaneously (12), which is much less than frequency of mentioned genes in present study. Deilami and Nasiri (13) reported that the frequency of the $h b l$ complex genes in B. cereus isolated from foodstuffs in Tabriz and Zanjan restaurants was 8\%, which is also much less than frequency of mentioned genes in present study. Prub et al. (14) reported that the prevalence of the hblA gene in B. cereus was $43 \%$. Reis et al. (15) reported that $36.5 \%$ of isolated B. cereus from pasteurized, sterilized and dry milk in Brazil had the $h b l$ complex genes. In another study, El-zamkan and Mubarak in Egypt (16), has been reported that the frequency of the hbl complex genes in B. cereus isolated from ice cream and rice-milk was $33.3 \%$ and $43.5 \%$, respectively (16). Differences in distribution of the $h b l$ complex genes in different $B$. cereus isolates in the mentioned studies probably are due to the geographical differences and the differences in ecological origin of isolated strains from milk, rice, meat, salads. Due to presence of all the three $h b l$ complex genes simultaneously in studied $B$. cereus isolates in this study, the hemolysin BL enterotoxin will have its maximum activity, and these isolates will potentially be highly pathogenic, if $h b l$ complex genes are expressed. Many factors affect the microbial quality of raw milk, which four factors considered as main sources in microbial contamination of raw milk. These resources include inside of livestock breast, exterior of livestock breast, environmental factors, and milking equipment and maintenance. Therefore, in order to provide hygienic milk and its products, health care must be respected according to Hazard Analysis and Critical Control Point (HACCP) instructions, during the production and consumption $(2,17)$. In general, the culture method and the biochemical tests are time-consuming and less accurate than the PCR method. Using the PCR test, in addition to being quicker, has more accuracy and confidence.

\section{Conclusion}

In this study, regarding that the most of the tested Bacillus cereus isolates harboured all the three $h b l$ genes, in the case of the expression of these genes, these isolates will have high virulence potentially.

\section{Acknowledgements}

The authors have supported all costs of the present research.

\section{Conflict of interest}

The authors declare that they have no conflict of interest.

\section{References}

1. Mahdavi S, Sadeghi Zali MS, Farajnia S, Mehmannavaz $Y$, Isazadeh A. The comparison of bovine fecal and buffy coat samples for diagnosis of Johne's disease based on PCR. Gene Cell Tissue. 2018;5:79745. Doi: $10.5812 /$ gct.79745

2. Moradi-Khatoonabadi Z, Maghsoudlou Y, Ezzatpanah H, Khomeiri M, Aminafshar M. Occurrence of Bacillus cereus in raw milk receiving from UF-feta cheese plants. Iran J Environ Health. 2014;6:545-556.

3. Shaheen R, Svensson B, Andersson MA, Christiansson A, SalkinojaSalonen M. Persistence strategies of Bacillus cereus spores isolated from dairy silo tanks. Food Microbiol. 2010;27:347-355. Doi: 10.1016/j.fm.2009.11.004

4. Sergeev N, Distler M, Vargas M, Chizhikov V, Herold KE, Rasooly A. Microarray analysis of Bacillus cereus group virulence factors. J Microbiol Meth. 2006;65:488-502. Doi: 10.1016/j.mimet.2005.09.013

5. Ceuppens S, Rajkovic A, Hamelink S, Van de Wiele T, Boon N, Uyttendaele M. Enterotoxin production by Bacillus cereus under gastrointestinal conditions and their immunological detection by commercially available kits. Foodborne Pathog Dis. 2012;9:1130-6. Doi: $10.1089 /$ fpd.2012.1230

6. Beecher DJ, Wong AC. Tripartite hemolysin BL: Isolation and characterization of two distinct homologous sets of components from a single Bacillus cereus isolate. Microbiol. 2000;146:1371-1380. doi.org/10.1099/00221287-146-6-1371.

7. Granum PE, O'Sullivan K, Lund T. The sequence of the nonhaemolytic enterotoxin operon from Bacillus cereus. FEMS Microbiol Lett. 1999;177:225-229. doi.org/10.1111/j.1574-6968.1999.tb13736.x

8. Beecher DJ, Schoeni JL, Wong ACL. Enterotoxin activity of hemolysin BL from Bacillus cereus. Infect Immun. 1995;63:44234428 .

9. Chang YH, Shangkuan YH, Lin HC, Liu HW. PCR assay of the groEL gene for detection and differentiation of Bacillus cereus group cells. Appl Environ Microbiol. 2003;69:4502-10. DOI: 10.1128/AEM.69.8.4502-4510.2003.

10. Hansen BM, Hendriksen NB. Detection of Enterotoxin Bacillus cereus and Bacillus thuringiensis Strains. Appl Environ Microbiol. 2001;67:185-189. Doi: 10.1128/AEM.67.1.185-189.2001

11. Mahdavi S, Azizi Dehbokri M, Isazadeh A. Contamination of chicken meat with salmonella spp distributed in Mahabad city, Iran. Int J Enteric Pathog. 2018;6:65-68. Doi: 10.15171/ijep.2018.18

12. Kim MJ, Han JK, Park JS, Lee JS, Lee SH, Cho JI. Various enterotoxin and other virulence factor genes widespread among 
Bacillus cereus and Bacillus thuringiensis strains. J Microbiol Biotechnol. 2015;25:872-879. DOI: 10.4014/jmb.1502.02003.

13. Deilami KZ, Nasiri SH. Isolation of Bacillus cereus from foods and studying the cytotoxicity of them on Vero cells. Quarterly J Anim Physiol Anim Dev. 2016;9:69-77.

14. Prub BM, Dietrich R, Nibler B, Martlbauer E, Scherer S. The hemolytic enterotoxin $H B L$ is broadly distributed among species of the Bacillus cereus group. Appl Environ Microbiol. 1999;65:5436-42. DOI: 10.1128/AEM.65.12.5436-5442.1999.

15. Reis ALS, Montanhini MTM, Bittencourt JVM, Destro MT, Bersot LS. Gene detection and toxin production evaluation of hemolysin BL of Bacillus cereus isolated from milk and dairy products marketed in Brazil. Braz J Microbiol. 2013;44:1195-1198. http://dx.doi.org/ 10.1590/S1517-83822013000400024

16. El-zamkan MA, Mubarak, AG. Detection of B. cereus and some of its virulence genes in some dairy desserts and children diarrhea. Alexandria J Vet Sci. 2017;53:28-38. Doi: 10.5455/ajvs.259758

17. Lues J, Venter P, Van Der Westhuizen H. Enumeration of potential microbiological hazards in milk from a marginal urban settlement in central South Africa. J Food Microbiol. 2003;20:321-26. Doi: 10.1016/S0740-0020(02)00128-4 